\title{
Edukacja leśna wsparciem kształcenia szkolnego
}

\author{
Anna Strumińska-Doktór, Małgorzata Jagodzińska \\ Państwowa Uczelnia Zawodowa im. Ignacego Mościckiego w Ciechanowie, ul. Narutowicza 9, 06-400 Ciechanów \\ gosia.jagod@gmail.com
}

\begin{abstract}
Streszczenie
Artykuł poddaje analizie istotę edukacji leśnej w kontekście jej wpływu na kreowanie postaw dzieci. Odwołując się do przykładów zajęć prowadzonych w lesie, mniej ustrukturyzowanych od prowadzonych w szkolnych klasach, pozwalających na większą samodzielność dzieci, przekonuje do stosowania różnych form edukacji leśnej, ponieważ bezpośredni kontakt z lasem daje lepsze możliwości poznania, odkrywania i zrozumienia przyrody oraz kształtowania kultury obcowania z lasem. Podkreśla się przy tym znaczenie form i treści edukacji leśnej dla kształtowania postaw prospołecznych. Dzieci posiadając większą swobodę działania, uczą się rozwiązywać problemy, podejmować decyzje, tworzyć reguły i przestrzegać ich oraz traktować z szacunkiem środowisko leśne, co przekłada się na szacunek wobec całej, otaczającej rzeczywistości.
\end{abstract}

\section{Słowa klucze}

edukacja leśna, ekologia, ochrona przyrody, leśne szkoły, zielone szkoły

\section{Wstęp}

W uchwalonej w 1991 r. nowoczesnej „Ustawie o lasach" można znaleźć wyraźne przesłanie o obowiązku Lasów Państwowych w zakresie edukacji przyrodniczo-leśnej. Początkowo leśnicy nieco chaotyczne działali w tym zakresie, starając się realizować zawarte w prawie trzy cele:

- upowszechnienie w społeczeństwie wiedzy o środowisku leśnym oraz o wielofunkcyjnej i zróżnicowanej gospodarce leśnej,

- podniesienie świadomości społeczeństwa w zakresie racjonalnego i odpowiedzialnego korzystania ze wszystkich funkcji lasu,

- budowanie zaufania społecznego do działalności zawodowej leśników (Ustawa z dnia 28 września 1991 r. o lasach Dz. U. z 1991 Nr 101 poz. 444).
Zagadnienia edukacji leśnej reguluje mniej lub bardziej szczegółowo kilka późniejszych dokumentów, jak np.: porozumienie Ministrów Edukacji Narodowej oraz Ochrony Środowiska, Zasobów Naturalnych i Leśnictwa z 1995 r. dotyczące opracowania i wdrażania „Narodowej strategii ekologicznej” lub przyjęty w 1997 r. przez Radę Ministrów dokument o nazwie "Polityka Leśna Państwa” mówiący o konieczności prowadzenia edukacji przyrodniczo-leśnej oraz promocji polityki leśnej.

Dokumenty te wskazują na priorytety:

- rozszerzenie wiedzy o funkcjonowaniu ekosystemów leśnych w programach szkół ponadpodstawowych oraz w szkolnictwie leśnym,

- prowadzenie szkoleń dla leśników z zakresu wielofunkcyjnej gospodarki leśnej, ekologii oraz ochrony przyrody, 
- organizowanie różnorodnych form dokształcania społeczeństwa w zakresie wiedzy przyrodniczo-leśnej,

- kształtowanie za pośrednictwem mediów wiedzy oraz postaw społeczeństwa wobec lasów i zasad ich ochrony i użytkowania,

- rozwijanie i doskonalenie działalności wydawniczej z zakresu edukacji leśnej,

- rozwijanie współpracy z ruchami ekologicznymi i organizacjami zainteresowanymi lasem i leśnictwem.

Pojęcie „leśnej edukacji” w sposób formalny pojawia się w dokumencie „Polityka leśna państwa”, ogłoszonym przez Radę Ministrów w dniu 22 kwietnia 1997 roku, w którym las traktowany jest jako uniwersalny obiekt edukacyjny. Od dawna był wykorzystywany w nauczaniu różnych przedmiotów, szczególnie przyrodniczych, a podejmowana w związku z poznawaniem jego tajemnic tematyka, związana była z integracją wielu przedmiotów i specjalności oraz zawierała szeroki zakres treści i metod nauczania.

Ideą wiodącą udoskonalonego dokumentu było przekonanie, że kontakt $\mathrm{z}$ lasem powinien być dla polskich dzieci najważniejszym sposobem poznania środowiska naturalnego.

Już w latach 90. ubiegłego wieku edukacja leśna, będąc obowiązkiem Lasów Państwowych, miała wpływ na rozwijanie przez leśników infrastruktury rekreacyjno-edukacyjnej i przyniosła wzrost upowszechniania w społeczeństwie wiedzy o lesie, wielofunkcyjnej i zrównoważonej gospodarce leśnej oraz kształtowaniu świadomości społeczeństwa na temat racjonalnego i odpowiedzialnego korzystania ze wszystkich funkcji lasu. W szkołach podstawowych zasadniczo była jednak tylko skromną częścią edukacji ekologicznej. Dopiero od 2003 roku zdecydowanie oddziela się te dwa typy edukacji - syntetycznie problem ten ujęto w Wytycznych do tworzenia Programu edukacji leśnej społeczeństwa w nadleśnictwie. Jest to załącznik do Zarządzenia nr 57 Dyrektora Generalnego Lasów Państwowych z 9 maja $2003 \mathrm{r}$. w sprawie wytycznych prowadzenia edukacji leśnej społeczeństwa w Lasach Państwowych, w którym formułuje się następujące cele edukacji leśnej:

1. upowszechnianie w społeczeństwie wiedzy o środowisku leśnym oraz o wielofunkcyjnej i zrównoważonej gospodarce leśnej,

2. podnoszenie świadomości społeczeństwa w zakresie racjonalnego i odpowiedzialnego korzystania z wszystkich funkcji lasu,

3. budowanie zaufania społecznego do działalności zawodowej leśników. Samo Zarządzenie wprowadziło do praktyki zawodowej nadleśnictw dokument zatytułowany Program edukacji leśnej społeczeństwa w nadleśnictwie, w którym zaleca się propagowanie treści zawartych w tematach:

- budowa i funkcjonowanie ekosystemów leśnych,

- znaczenie (funkcje) lasu: ekologiczne, produkcyjne i społeczne,

- ochrona przyrody,

- zadania leśników i leśnictwa.

Analizując treści tego dokumentu można wskazać na istotę różnicy między edukacją ekologiczną a leśną. Pierwsza, analizuje i przedstawia relacje człowieka ze składnikami natury, między innymi z lasem, a druga koncentruje się na relacjach między lasem a człowiekiem.

Realizując obowiązki prawne, kierownictwo Lasów Państwowych kieruje się przede wszystkim zasadą, że efektywność edukacyjna jest pochodną różnorodności i mając na względzie kształtowanie określonych postaw już u najmłodszych, wspiera ciekawe projekty i zróżnicowane sposoby osiągania celów edukacji leśnej. Należy jednak zwrócić uwagę, że Lasy Państwowe nie wyręczają resortu oświaty, ani nie konkurują z innymi podmiotami prowadzącymi edukację ekologiczną społeczeństwa, ale dysponując dobrze wykształconą kadrą starają się wypełnić lukę w systemie edukacji dotyczącą lasów i leśnictwa oraz przyczynić się do kształtowania proekologicznych postaw najmłodszych. 


\section{Formy edukacji leśnej dla dzieci}

Wszystkie nadleśnictwa, niezależnie od specyfiki i lokalizacji, w każdym Leśnym Kompleksie Promocyjnym zatrudniają przynajmniej jednego pracownika Służby Leśnej na stanowisku specjalisty lub starszego specjalisty ds. edukacji leśnej. W każdej regionalnej dyrekcji Lasów Państwowych wyznaczono pracownika koordynującego zadania z zakresu edukacji leśnej, odpowiedzialnego za opracowanie programu edukacji leśnej. Pozwala to na stosowanie dużej różnorodności działań edukacyjnych, a standardem jest 2-3 godzinny pobyt grupy na terenie nadleśnictwa, $\mathrm{z}$ określonym wątkiem edukacyjnym uzupełnionym przez różne formy zabawy. Dziesięcioletnie programy edukacji leśnej sporządza się w ramach planów urządzenia lasu i są one nadzorowane przez „Komisję programu edukacji leśnej w nadleśnictwie". W skład Komisji wchodzą: zajmujący się edukacją pracownik nadleśnictwa, koordynator edukacji leśnej na szczeblu regionalnej dyrekcji Lasów Państwowych oraz przedstawiciele lokalnych instytucji i organizacji zajmujących się edukacją ekologiczną. Program edukacji leśnej jest zatwierdzany przez dyrektora Regionalnej Dyrekcji Lasów Państwowych. (Chrzanowski, 2016)

Programy, poza określeniem formy zajęć, zawierają opis walorów obiektów edukacji leśnej (ośrodków edukacji leśnej, izb leśnych, ścieżek edukacyjnych, parków i ogrodów dendrologicznych i botanicznych, punktów edukacji leśnej i rezerwatów przyrody udostępnionych do celów edukacyjnych), listę potencjalnych partnerów (szkół, ośrodków edukacji ekologicznej, parków krajobrazowych i narodowych, samorządów, mediów i organizacji pozarządowych) oraz listę wydawnictw edukacyjnych. (Tamże)

Edukacja przyrodniczo-leśna, kreowana i realizowana głównie przez leśników, jest przede wszystkim uzupełnieniem wiedzy nabywanej w ramach zajęć szkolnych. Dzieci ze szkół podstawowych są najczęstszymi adresatami edukacji w Lasach Państwowych, więc zważywszy na specyfikę kształcenia na tym poziomie, zarówno materiały edukacyjne, jak i sposoby ich prezentacji są starannie przygotowywane $\mathrm{z}$ uwzględnieniem możliwości percepcyjnych uczniów. W roku 2016 liczba uczniów szkół podstawowych uczestnicząca w edukacji leśnej organizowanej w lasach Państwowych przekroczyła 800 tysięcy (Wykres 1). Liczba dzieci i młodzieży maleje z każdym, wyższym etapem edukacyjnym. Uczniowie szkół podstawowych to wymagający uczestnicy zajęć. Realizując odpowiednie formy, leśnicy zazwyczaj zaczynają od „abecadła przyrodniczego”.

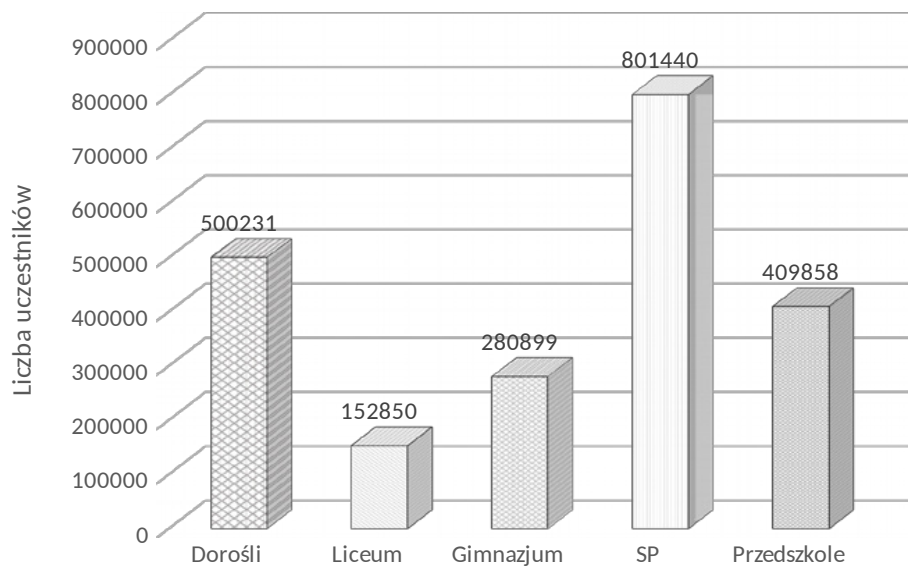

Wykres 1. Uczestnicy edukacji leśnej w Lasach Państwowych w 2016 r.

Źródło: Raport z działalności edukacyjnej Lasów Państwowych, 2016 
Kluczem do sukcesu w edukacji leśnej będą tu umiejętności posługiwania się przez „edukatorów” zróżnicowanymi formami, zarówno biernymi, jak i czynnymi. Pierwsze, bazują na tworzeniu ścieżek dydaktycznych, działalności wydawniczej, opracowaniach multimedialnych i uczestnictwie w wystawach oraz konkursach. Natomiast formy aktywne na bezpośrednim, synergicznym kontakcie ucznia z edukatorem. Najczęściej stosuje się wycieczki z odpowiednio przygotowanym przewodnikiem - leśnikiem, zajęcia w izbach edukacyjnych, imprezy organizowane przez leśników, takie jak sadzenie lasu, zielone lekcje, leśne stoisko na targach lub festynie i konkursy. Nadleśnictwo włącza też dzieci w coroczne akcje typu "Sprzątanie Świata”, „Pomóżmy Kasztanowcom” czy „Dzień Ziemi”. Obiektem najchętniej odwiedzanym przez dzieci są ścieżki edukacyjne, zwane też dydaktycznymi lub poznawczymi - są to trasy o długości około 2-4 km, wiodące przez tereny leśne, z kilkoma, czasem kilkunastoma, przystankami tematycznymi, o bardzo różnorodnym zagospodarowaniu. (Sieradzki, 2008)

Edukacja leśna obejmuje głównie zagadnienia służące uświadomieniu dzieciom znaczenia lasów dla środowiska życia człowieka, zasad funkcjonowania ekosystemów leśnych, racjonalnego użytkowania zasobów leśnych, znaczenia zawodowej pracy leśników oraz zagrożenia przyrody i jej ochrony. Do prowadzenia zajęć wykorzystuje się charakterystyczne punkty fizjograficzne, eksponaty, a także zespoły przyrodnicze, wokół których budowany jest przekaz „od szczegółu do ogółu”. Ważnym elementem edukacyjnym są tablice informacyjne, znajdujące się najczęściej przy wjazdach do lasu, szczególnie w okolicy miast oraz przy każdym miejscu w lesie, które ze względu na swój przyrodniczy charakter jest wyjątkowe i godne uwagi. Zawierają najważniejsze informacje dotyczące lasu, zakazy i nakazy, a także opis miejsc, które warto odwiedzić. (Lasy Państwowe w liczbach, 2018). Dzięki nim dzieci dowiadują się, że w lesie zabroniony jest ruch pojazdów poza drogami publicznymi, nie wolno: parkować i biwakować poza miejscami wyznaczonymi, zakłócać ciszy, rozniecać ognia i palić tytoniu, puszczać psów luzem, płoszyć i zabijać zwierząt, zaśmiecać gleby i wód, niszczyć drzew i innych roślin, rozkopywać gruntu i rozgarniać ściółki oraz niszczyć urządzeń, obiektów turystycznych, tablic i znaków informacyjnych.

W latach 9o. ubiegłego wieku w krajobrazie polskich lasów nie występowały urządzenia zabawowe wspomagające proces edukacji przyrodniczo-leśnej. Obecnie leśnicy mają do dyspozycji różnego typu łamigłówki w postaci krzyżówek, plansz, obrotowych walców wypełnionych treścią o tematyce leśnej, puzzle, labirynty natury, kostki wiedzy, Swiatowidy i skrzynki Zgaduj-Zgadula. Oferta produkcyjno-handlowa najbardziej znanych firm, zajmujących się wyposażeniem leśnych obiektów edukacyjnych, jest bardzo atrakcyjna - umożliwia instalację urządzeń angażujących nie tylko dotyk, ale też słuch i węch, co jest szczególnie ważne w edukacji uczniów niepełnosprawnych (zwłaszcza niewidzących). Pomagają one pobudzać aktywność psychomotoryczną, ułatwiają wspólną zabawę dzieci pełno i niepełnosprawnych, czyli rozwijanie więzi międzyludzkich, a w konsekwencji służą prawidłowej egzystencji społecznej. (Woźnicka, Janeczko, Kargul-Plewa, 2016, s. 195)

Edukacyjny charakter często mają też nawierzchnie występujące $\mathrm{w}$ sąsiedztwie przestrzeni zabawowych. Dużo radości sprawia dzieciom ścieżka zmysłów, inaczej określana ścieżką czuciową, przeznaczona do chodzenia boso. Wykonywana jest z rożnych materiałów pozyskiwanych z lasu jak: kora, bukiew, szyszki, żołędzie, igły sosnowe itp. Czasem w nawierzchni ścieżek umieszcza się drewniane panele lub gipsowe odlewy elementów roślinnych lub tropów zwierzęcych.

Dla młodszych dzieci dużą atrakcją są specjalne piaskownice, czasem imitujące kształt granic parku narodowego (np. w Białowieskim Parku Narodowym), w których, w zależności od rodzaju posiadanego wyposażenia, można ukrywać modele szkieletów 
prehistorycznych zwierząt, projektować różne rodzaje zadrzewień, odciskać tropy zwierząt, itp. Popularnością cieszą się też przeskalowane, wykonane w bardzo dużym powiększeniu modele owadów, grzybów itp. wykonane z dużą dbałością o dokładne przedstawienie budowy morfologicznej pierwowzorów, pozwalające na lepsze poznanie anatomii poszczególnych osobników (Czołnik 2005).

Od niedawna w Polsce realizowana jest idea szkół i przedszkoli leśnych, stosowana od kilkudziesięciu lat w krajach skandynawskich, Japonii, Szwajcarii, Niemczech, Wielkiej Brytanii, USA czy Kanadzie, w Skandynawii i Czechach. Stanowi tam stały element systemu edukacyjnego, finansowany głównie przez ministerstwo. Według Forest Education Initiative szkoły leśne zostały zdefiniowane jako inspirujacy proces, który oferuje dzieciom, mtodzieży a nawet osobom dorostym możliwość rozwijania pewności siebie i poczucia wtasnej wartości poprzez samodzielne uczenie sie w leśnym środowisku. (Budniak, 2009, s.32).

U źródeł polskiego przedsięwzięcia (bazującego na współpracy między placówkami oświatowymi a Nadleśnictwem), znajdują się ogólne cele pedagogiczne, związane z edukacją holistyczną, traktowaniem dziecka jako odkrywcy i naśladowcy. Stworzona jest przestrzeń dla inicjowanych przez dziecko zabaw w naturze, postrzeganiem zmysłowym oraz rozwojem motorycznym jako fundamentem procesu uczenia się, wreszcie z kształtowaniem osobowości i nakłanianiem dziecka do odpowiedzialności oraz odpowiedniego funkcjonowania w grupie.

Przykładem jest przedszkole „Puszczyk”, w którym dzieci cały czas spędzają na podwórku, a jako baza służy im jurta mongolska usytuowana na terenie siedziby Nadleśnictwa Dojlidy, które współpracuje z placówką. Okazuje się, że dzieci w wieku od 2,5 do 5 lat potrafią nawet w czasie srogiej zimy spędzać po 6-7 godzin na świeżym powietrzu, są szczęśliwie, prawie nie chorują, a maluchom z alergią znacząco złagodniały jej objawy. (Dzieci są ważne, 2018).
Zazwyczaj placówki te, poza wprowadzaniem w świat przyrody, opowiadaniem o tym, co może się zdarzyć, jaka przygoda czeka dzieci w czasie zabaw w plenerze, dbają o aspekt zdrowotny zajęć, chociażby taki, jak zmiany w wydolności fizycznej i termicznej dzieci. Szkoły leśne pod nadzorem wykwalifikowanych opiekunów i z zachowaniem zasad bezpieczeństwa wykorzystują tereny leśne do swobodnych zabaw bez narażania dzieci na ryzyko, umożliwiając poznawanie świata za pomocą różnych zmysłów oraz rozwijanie kreatywności i wyobraźni. Rezygnacja z przebywania w budynku, posługiwanie się wiatą umiejscowioną w lesie, gwarantuje regularny kontakt $\mathrm{z}$ naturą bez względu na porę roku i temperaturę. $\mathrm{Na}$ uczycielom pozwala to wyjść poza edukacyjny szablon i doświadczyć zupełnie nowego stylu przekazywania wiedzy, opartego z jednej strony na pracy zespołowej, a z drugiej na samodzielnym poszukiwaniu odpowiedzi, bezpośrednim doświadczaniu i poleganiu na sobie.

Przedszkola i szkoły leśne, hołdując metodzie „nauki przez zabawę", uczą wielu przydatnych umiejętności życiowych, zamiast wirtualnych gier i innych „cudów” technologii oferują prawdziwe poszukiwanie skarbów, zabawę kijkami, kamieniami, kwiatami, przy wykorzystaniu drzew czy robaków. Przykładem typowej, polskiej leśnej klasy, jest powstała w 1999 r., w Leśnictwie Szkółkarskim Kolonia, Leśna klasa edukacyjna. Wyposażono ją w ławki i stoliki oraz liczne tablice z barwnymi, szczegółowo opisanymi fotografiami. Wokół klasy stworzono ekspozycję naturalnych form, występujących w stanie dzikim, najbardziej pospolitych drzew i krzewów występujących w Polsce. Drzewa i krzewy występują tu w grupach po kilka sztuk z nazwami w języku polskim i łacińskim. Tabliczki z napisem zorientowano do środka alei głównej, żeby można było przeprowadzić sprawdzian z rozpoznawania poznanych gatunków.

Obok klasy, z różnej wielkości głazów występujących w regionie, zbudowano skalniak $\mathrm{z}$ oczkiem wodnym. Umieszczono tam wiele 
gatunków roślin: konwalia majowa, tawuła japońska, winobluszcz pięciolistny, jałowiec pospolity, sosna górska, barwinek, daglezja zielona, cyprysik groszkowy i Lawsona, cis pospolity, żywotnik zachodni i wiele innych.

Żeby zapoznać dzieci z problemem dokarmiania zwierzyny, na terenie klasy ustawiono urządzenia służące do tego celu. Zwierzynie płowej (jeleń, sarna) podaje się karmę w paśnikach, które budowane są z materiałów naturalnych, aby swoim wyglądem nie odstraszyły zwierząt. Ustawia się je w rzadszych drzewostanach lub na polankach w pobliżu gąszczu, by w czasie niebezpieczeństwa zwierzęta mogły się szybko schronić ( Edukacja leśna - Wydawca treści - Lasy Państwowe, 2018). Dzieci mogą uczestniczyć w dokarmianiu, np. ustawiają w paśnikach tzw. Lizawki, czyli cegiełki soli kamiennej, zawierające sole mineralne niezbędne do prawidłowego funkcjonowania organizmu zwierzęcego.

Bardzo ważną formą edukacji leśnej jest odwiedzanie parków narodowych i rezerwatów przyrody, gdzie obowiązują najbardziej surowe zasady zachowania. Dzieci poznają w ten sposób miejsca wyjątkowe, dowiadują się o rzadkich roślin i zwierzętach, objętych szczególną opieką. Ponieważ każdy park narodowy posiada straż, która pilnuje przestrzegania przepisów związanych z troską o zachowanie przyrody w niezmienionym stanie oraz zasad bezpieczeństwa zwiedzających, dzieci nie tylko kształtują wiedzę o leśnym świecie, poznają jego tajemnice, strukturę, funkcjonalność i mieszkańców leśnego ekosystemu, ale też zaznajamiają się z pracą leśnika, jako gospodarza lasu, z jego rolą w hodowli i ochronie lasu.

Richard Louv, jeden z popularyzatorów tej idei w Stanach Zjednoczonych, przekonuje do leśnych szkół, podkreślając benefity płynące ze spędzania czasu wśród natury:

- dzieci uczą się pewności siebie, bo w lesie przekonują się, iż każdy jest równy, unikatowy, wartościowy, zdolny do tego, by samodzielnie odkrywać świat i ma prawo do podejmowania ryzyka i wyzwań,
- dzieci stają się bardziej odporne na choroby, poprawiają umiejętność koncentracji, obserwacji, rozwiązywania problemów,

- zabawy w terenie sprzyjają pracy zespołowej i wymyślaniu własnych gier, co przekłada się bezpośrednio na lepsze wyniki w naukach ścisłych,

- dzieci rozwijają silną relację z otaczającym go światem i przyrodą. (Louv, 2016)

Działania jednostek administracyjnych Lasów Państwowych w zakresie edukacji przyrodniczo-leśnej, powinno postrzegać się jako płaszczyznę ścisłej współpracy ze szkołami. Wiele $\mathrm{z}$ nich można $\mathrm{z}$ powodzeniem realizować w klasach szkolnych. Można wówczas wykorzystać liczne pomoce. Np. tablice interaktywne „Odgłosy lasu” doskonale pobudzają wyobraźnię i gwarantując zabawę, stanowią skuteczną formę edukacji. Posiadają regulację głośności, zasilane są napięciem $230 \mathrm{~V}$ oraz dodatkowo wyposażone są we wbudowany akumulator, który po naładowaniu wystarcza na ok. 2 h zabawy zarówno w klasie, jak i na świeżym powietrzu. Dźwięki lasu zostały nagrane przez specjalistów z BBC Natural History Unit i National Geographic w polskich lasach. Poszerzaniu wiedzy z zakresu rozpoznawania drzew i krzewów służą zestawy typu: „Zgadnij z jakiego to drzewa”, „Zestaw małego dendrologa” czy „Zgadnij jaki to grzyb?” (Mrowińska, 2008).

Nauczyciele w szkołach mogą też realizować niektóre propozycjeLasów Państwowych, które często stanowią dydaktyczną formę urozmaicania zajęć lekcyjnych, np. spotkania z ciekawymi, posiadającymi ogromnąwiedzę przyrodniczą ludźmi, prelekcje o przyrodzie, polskich lasach, funkcjonowaniu gospodarki leśnej w Polsce nazasadach zrównoważonego rozwoju czy racjonalnego postępowania w duchu ochrony przyrody.

Niezależnie od wyboru form, należy pamiętać, aby dziecko na tych zajęciach było podmiotem, a nie widzem, żeby przekazywaniu treści towarzyszyło przeżywanie, 
radość z odkrywania, inspirowanie do rozwijania wrażliwości na piękno, dobro, otaczający świat. Najwyższa frekwencja była odnotowana w $2016 \mathrm{r}$ w akcjach edukacyjnych organizowanych przez Lasy Państwowe (Wykres 2). Ponad pół miliona dzieci i młodzieży uczestniczyło w zajęciach terenowych prowadzonych przez leśników i specjalnie przygotowanych edukatorów. Izby edukacji leśnej przyjęły ponad 300 tysięcy uczniów chcących zgłębić tajniki lasu.

\section{Oddziaływanie edukacji leśnej na postawy dzieci}

Las to okazja dla dzieci do doświadczania wspólnych, ciekawych przeżyć, pokazujących wartość przyrody i zależności między żywymi organizmami a ich środowiskiem oraz wpływy człowieka na procesy zachodzące w przyrodzie (Płoskonka, Dzioban, 2012, s.37). Dzieci zazwyczaj są bacznymi obserwatorami - poznając dokładnie warunki życia w lesie, pieczołowicie badają zależności w przyrodzie oraz to, jaki wpływ ma człowiek na otaczające środowisko. Szybko budzi się w nich ciekawość przyrodnicza, uzmysławiają sobie, że przyroda żyje i należy ją szanować. W trakcie zajęć szukają odpowiedzi na wiele pytań, kształtuje się w nich emocjonalna więź z lasem i budzi troska o środowisko naturalne. Stworzenia, które wcześniej budziły lęk (np. dzik, wilk, lis) albo wstręt (np. jaszczurka zwinka, mysz leśna czy ropucha szara) stają się bliskimi, akceptowanymi.

Powszechnie oczekiwanymi efektami realizacji zadań z zakresu edukacji leśnej są: rozbudzenie wrażliwości na problemy środowiska naturalnego, rozwijanie wyobraźni i przekonanie, że czas spędzony na łonie natury jest szczególnie interesujący, wyzwala kreatywność i jest źródłem wielu radości.

Edukacja leśna, pozwalając na kształtowanie w sposób szczególny indywidualności dziecka ułatwia wyzwalanie w dzieciach przekonania, że każdy może przeżywać kontakt z naturą na swój sposób. Dlatego dzieci w lesie czują się swobodnie - jedne radość afirmują skacząc, pląsając czy śpiewając, inne słuchają odgłosów ptaków, kontemplują otoczenie albo zbierają leśne skarby. Wszystkie zazwyczaj bardzo szybko uruchamiaja wyobraźnię i kreatywność - w ich rączkach kamienie, patyki i szyszki szybko przeobrażają się w zabawki, np. koniki, samochodziki, dzidziusie itp., a las staje się magiczną przestrzenią pełną kryjówek i miejsc, w których można przeżywać nowe przygody, co wcale nie wyklucza czasu na naukę treści przewidzianych w podstawie programowej czy na odpoczynek.

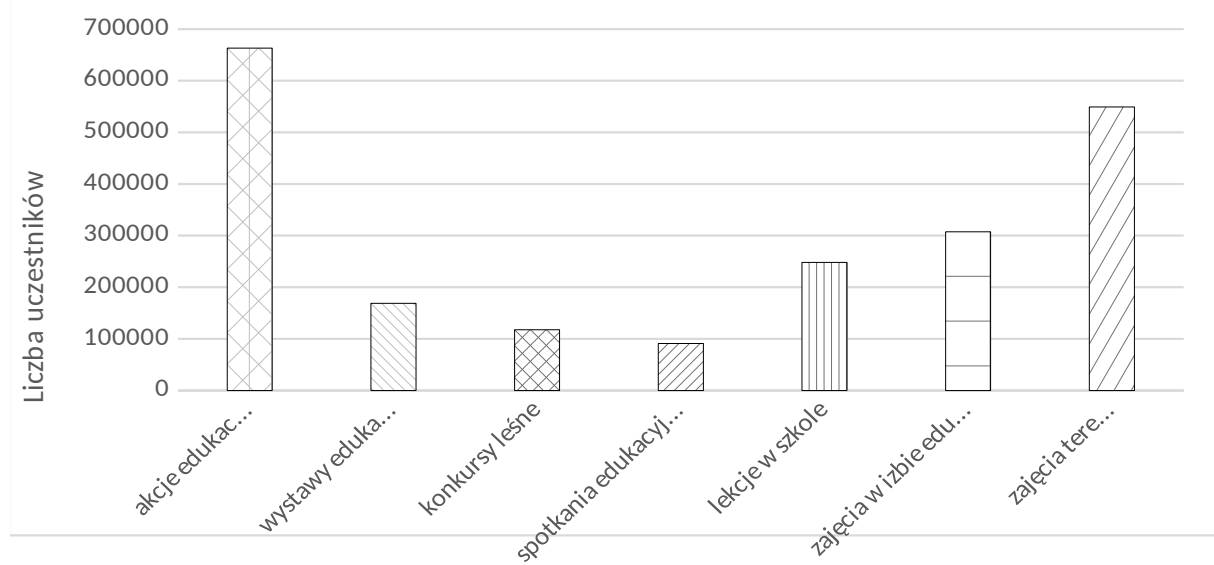

Wykres 2. Formy edukacji w Lasach Państwowych i frekwencja w 2016 r.

Źródło: Raport z działalności edukacyjnej Lasów Państwowych, 2016 
Terenowa forma zajęć z edukacji leśnej ma zazwyczaj wpływ na większe zainteresowanie środowiskiem naturalnym - możliwość bezpośredniego kontaktu z poszczególnymi gatunkami drzew i krzewów czy zwierząt, nie tylko ułatwia przyswojenie wiedzy. Dzieci dowiadując się, że w naszych lasach żyją wilki, bobry, żubry oraz wiele gatunków roślin, które zniknęły z lasów europejskich, odczuwają dumę i nabierają szacunku do ciężkiej pracy leśników.

Przekonując się, że rosnące w lesie zioła oraz takie elementy jak liście niektórych drzew i krzewów, łodygi, kwiaty, pączki, nasiona, kora, owoce, kłącza mają działanie lecznicze, (czasem identyczne jak leki syntetyczne, ale można je stosować przez dłuższy czas bez obaw na działania uboczne) częściej z ochotą wypijają herbaty ziołowe, albo napary, które podaje mama czy babcia. Z drugiej strony, pouczane, że niektóre zioła czy owoce zawierają związki trujące (np. pokrzyk wilcza jagoda) starają się zapamiętać i nie dotykać tych, których niewłaściwe spożycie może prowadzić do zatrucia lub nawet śmierci.

Jednak nadrzędnym celem każdego programu jest skuteczne i efektywne kształtowanie postaw dzieci zgodnych z etyką ekologiczną. Odpowiednio realizowany program daje realną szansę na trwałe rozbudzenie u dzieci poczucia związku ze środowiskiem naturalnym, potrzeby kontaktu z przyrodą, uwrażliwienie na jej piękno i harmonię, kształtowanie szacunku dla niej czy też, a także motywowanie do zachowań przeciwdziałających degradacji środowiska, uczestnictwa w inicjatywach mających na celu ochronę i zapobieganie dewastacji przyrody, do opieki nad zielenią wokół szkoły, zrzeszania się w kołach ekologicznych, właściwego przeznaczania odpadów i nie zaśmiecania środowiska,.

Leśnicy, poprzez wcześniej opisane formy, wpływają na pozytywne zachowania dzieci w różnych sytuacjach, szczególnie w kontaktach z istotami żywymi, zachęcają do praktykowania ekologicznego życia we własnym domu, w różnych sytuacjach szkolnych i pozaszkolnych, uczą tolerancji, przeciwstawiania się agresji. Inicjując wspólne, konkretne, działania na rzecz ochrony środowiska, jednoczą dzieci z różnych środowisk i rozwijają umiejętności harmonijnego współistnienia i współdziałania z ludźmi i z przyrodą. Jest to dobry sposób na wprowadzanie młodego pokolenia w życie społeczne - leśna edukacja może być więc dla dzieci pomostem wprowadzającym w życie społeczne i przygotowującym do pełnienia określonych funkcji społecznych.

Wykonując zadania w terenie, dzieci rozwijają sprawność fizyczną, a poznając przy okazji piękno otoczenia, budzą w sobie ochotę na rozwijanie zainteresowania wieloma zjawiskami przyrody poprzez rysunek, malarstwo czy fotografie, więc możemy powiedzieć, że edukacja leśna wpływa na doskonalenie ich umiejętności w tych dziedzinach. Podobnie jest $\mathrm{z}$ utrwalaniem wiedzy w zakresie posługiwania się mapkami okolicy, przewodnikami, atlasami, funkcjonującymi na rynku wydawniczym publikacjami - kluczami do oznaczania roślin, folderami itp. Wykonywane w tym kierunku ćwiczenia dodatkowo służą rozwojowi perspektywicznego myślenia i przewidywania skutków określonej działalności człowieka, co czyni dzieci sprzymierzeńcami w piętnowaniu zachowań zagrażających lasom, takich jak np. zaśmiecanie lasów czy wypalanie traw.

Edukacja leśna przynosi też wiele pozytywnych oddziaływań na rodziców dzieci, którzy w określonych sytuacjach stają się współtwórcami procesu edukacyjnego. Angażując się w organizowanie wycieczek, pomagając przy wykonaniu trudniejszych zadań, wymagających negocjacji, empatii, strategicznego myślenia, mimowolnie kształtują w dzieciach postawy pozytywnie wpływające na zintegrowanie życia rodzinnego, atrakcyjne spędzanie czasu wolnego, a także rozwijanie poczucia własnej wartości i własnych możliwości. Wspólne zabawy w lesie, zbieranie grzybów, udział w takich przedsięwzięciach jak podchody, budowanie szałasu, marsz na orientację dzieci nabywają 
sprawności i nabierają pewności, że poradzą sobie w trudnych sytuacjach. Dzieci, pod wpływem nowych emocji, lepiej poznają siebie i swoich najbliższych w innym otoczeniu niż dom. Dzięki trudniejszym zajęciom zdobywają nowe umiejętności techniczne, związane przede wszystkim z przetrwaniem i zachowaniem się w trudnych warunkach terenowych, a także kompetencje społeczne takie jak umiejętność współpracy w zespole, podejmowania właściwych decyzji, a nawet umiejętność bycia liderem.

Dzięki edukacji leśnej coraz więcej dzieci ma świadomość ogromnych korzyści, jakie czerpiemy z lasu i ochrony przyrody bazującej na wspólnej odpowiedzialności za jej stan. Las to możliwość zdobywania wielu doświadczeń, które powodują wzrost motywacji dzieci do rozwijania umiejętności postrzegania, rozumienia procesów oraz zjawisk przyrodniczych i do nauki. Zajęcia w lesie mogą stać się świetnym narzędziem pedagogicznym, kształtującym cechy charakteru. Stosowane w takich specyficznych warunkach gry i ćwiczenia służą rozwojowi funkcjonowania w grupie, skłaniają do refleksji jak można nabyte umiejętności wykorzystać w życiu szkolnym, w pokonywaniu życiowych przeszkód i pokonywaniu wyzwań, jakich doświadczamy w codzienności. Dzieci, przeżywające przygody w naturalnym środowisku, lepiej rozwijają koncentrację i inne kompetencje, które mają głęboki sens w kontekście rozwoju człowieka

\section{Podsumowanie}

Las, jako sceneria dla edukacji realizującej zadania o charakterze poznawczym, wychowawczym i rekreacyjnym, mobilizuje leśników oraz nauczycieli do doboru form i treści z zakresu edukacji przyrodniczo-leśnej. Spoczywa na nich duża odpowiedzialność związana z kształtowaniem postaw dzieci i wyrabianiem w nich proekologicznych nawyków. Starając się łagodzić negatywne wpływy nowoczesnej cywilizacji, poprzez jak najczęstszy pobyt w nienaruszonej przyrodzie oraz poprzez zachowywanie nieskażonych darów przyrody, na ile to możliwe w warunkach dzisiejszego życia, muszą mieć świadomość, że działania wpisujące się w nurt edukacji przygodowej nie moga być przypadkowe. Dostosowując program do potrzeb i możliwości dzieci nie wolno zapominać o tzw. kontrolowanym ryzyku. Zawsze obecne podczas zajęć w lesie ryzyko nadaje im charakter przygody i służy intensyfikacji przeżyć zarówno w sferze emocjonalnej, jak i poznawczej. Pozwala uczestnikom sprawdzić się w sytuacjach trudnych i kształtować umiejętność opracowywania strategii zachowania się w warunkach stresogennych. Dlatego prowadzący muszą umiejętnie uświadamiać młodych uczestników o konieczności brania odpowiedzialności za własne decyzje i ponoszenia ewentualnych konsekwencji. Dzieci nie mogą być izolowane od świadomości grożącego im niebezpieczeństwa oraz niepewności przebiegu i wyniku niektórych przedsięwzięć, co w przypadku dzieci może być źródłem silnych emocji. Dlatego ważnym elementem zadań edukacji leśnej zawsze będzie analiza własnego zachowania i zachowania kolegów, określania zarówno pozytywnych, jak i negatywnych zjawisk oraz realnego oceniania relacji pomiędzy poszczególnymi uczestnikami. Szczególnych starań w tym zakresie wymaga edukacja leśna dotycząca szkół podstawowych w dużych aglomeracjach miejskich, gdzie dzieci rzadziej mają spontaniczny kontakt z lasem i gdzie więcej wysiłku wymaga zachęcenie nauczycieli do aktywności w zakresie korzystania z bazy Lasów Państwowych, chociażby z powodów organizacyjnych. Warto jednak podejmować starania o rozwój edukacji leśnej szczególnie w takich środowiskach, gdzie cywilizacja zdominowała naturę, gdyż z perspektywy rozwoju psychofizycznego, poprzez budowanie potrzeby kontaktu z przyrodą, rozbudzanie wyobraźni i zwiększanie odporności na choroby, stanowi ona jeden z najlepszych sposobów na naukę samodzielności, wiary w siebie i swoje umiejętności oraz zapewnienie optymalnych warunków do rozwoju. 


\section{Bibliografia}

Budniak A. 2009. Edukacja społeczno-przyrodnicza dzieci w wieku przedszkolnym i młodszym szkolnym, Kraków.

Chrzanowski T. 2016. Model edukacji leśnej społeczeństwa w Lasach Państwowych, Studia i Materiały CEPL w Rogowie R. 18. Zeszyt 47 / 2.

Czołnik B. 2005. Spotkanie z lasem. Las w pytaniach $i$ odpowiedziach. Ośrodek Kultury Leśnej, Gołuchów.

Czołnik B. 2005. Wystawy w edukacji leśnej. [w:] Poradnik Edukacji Leśnej zeszyt 19. Antczak A. Milewski W.[red.] CILP Warszawa.

Louv R. 2016.Ostatnie dziecko lasu, tłum. A. Rogozińska, Grupa Wydawnicza Relacja, Warszawa.

Miś R., Strzeliński P. 2ooo. Zasady projektowania ścieżek edukacyjnych w lasach. [w:] Problemy turystyki i rekreacji w lasach Polski, AWF, Warszawa.

Mrowińska I. 2008. Edukacja leśna jako innowacja pedagogiczna. [w] Antczak A. 2003-2009. Poradnik Edukacji Leśnej. CILP, Warszawa.

Paschalis P. 1998. Użytkowanie lasu: znane problemy? Użytkowanie lasu i problemy regulacji użytkowania lasu w Polsce. Fundacja Rozwój SGGW. Warszawa.
Płoskonka P., Dzioban K. 2012. Las miejscem edukacji przygodowej na przyktadzie zajęć z surwiwalu. Stud. i Mat. CEPL, Rogów, 3 (32): 36-44.

Sieradzki W. P. 20o8. Totalna jakość edukacji leśnej, Studia i Materiały Centrum Edukacji Przyrodniczo-Leśnej R. 10. Zeszyt 2 (17)

Ważyński B. 1997. Urzadzanie i zagospodarowanie lasu dla potrzeb turystyki i rekreacji. AR, Poznań.

Woźnicka M., Janeczko E., Kargul-Plewa D. 2016. Walory edukacyjne urzadzeń zabawowych $w$ lasach, Studia i Materiały CEPL w Rogowie R. 18. Zeszyt 47 / 2.

(web-o1) Edukacja leśna - Wydawca treści - Lasy Państwowe, www.oleszyce.krosno.lasy.gov.pl/ obiekty-edukacyjne (dostęp z dnia 12.05.2018)

(web-o2) https://dziecisawazne.pl/lesne-przedszkole (dostęp z dnia 12.05.2018)

(web-03) https://www.mos.gov.pl/srodowisko/lesnictwo (dostęp z dnia 11.05.2018)

(web-o4) www.lasy.gov.pl/pl/informacje/publikacje/.../lasy-w-liczbach-2017 (dostęp z dnia 12.05.2018).

\section{Forest schooling as a supplement to school education}

\section{Abstract}

The article analyses the essence of forest education in the context of its impact on shaping children's attitudes. Referring to examples of forest activities, less structured than activities in school classes and allowing for greater independence for children, it argues for using various forms of forest education, because direct contact with the forest gives better opportunities to know, discover and understand nature and shape a culture of communing with the forest. At the same time, the importance of the forms and content of forest education for shaping pro-social attitudes is emphasised. Children with greater freedom of action learn to solve problems, make decisions, create rules and observe them and treat the forest environment with respect, which translates into respect for the whole world around them.

\section{Keywords}

forest education, ecology, nature protection, forest schools, green schools 